\title{
Values and Violence Endorsement Among College Students in Turkey
}

\author{
Veysel Bozkurt \\ Hakan Gülerce
}

\begin{abstract}
This study examines the impact of values on approval of violence. Data was collected from university students with a stratified random sample. The results showed that violence endorsement has a statistically significant positive correlation with tradition, stimulation and power values, whereas universalism, security, conformity, and benevolence values have negative correlations with violence endorsement. The approval of violence did not have any significant relationship with self-direction, hedonism and achievement values. The effects of violence exposure and gender on violence approval were also examined and both were determined to be highly influential. However, the main theme of the research was the effect of values on violence endorsement. Multiple regression analysis showed that the most important predictor values are universalism, stimulation, tradition and power values. The absolute antidotes to violence were the universal values of equality, wisdom, peace, tolerance and nature conservation etc. Greater importance given to these universal values in education policies could help to reduce the endorsement of violence..
\end{abstract}

Keywords: Values, violence endorsement, exposure to violence, gender, college students.

Öz: Bu çalışma, şiddetin onaylanmasında değerlerin etkisini incelemektedir. Data, tabakalı-tesadüfi örneklem yöntemiyle üniversite öğrencilerinden toplanmıştır. Sonuçlar, şiddetin onaylanması ile gelenek, teşvik ve güç değerleri arasında istatistiksel olarak önemli düzeyde pozitif bir korelasyon, buna karşıllk şiddetin onaylanması ile evrensellik, güvenlik, uyum ve hayırseverlik arasında negatif bir korelasyon olduğunu göstermektedir. Şiddetin onaylanması ile öz-yönelim (özerklik), hazcılık ve başarı değerleri arasında anlamlı bir iliş̧i bulunmamıștır. Şiddetin onaylanmasında cinsiyetin ve şiddete maruz kalmanın etkisi de incelenmiş ve ikisinin de oldukça etkili olduğu tespit edilmiştir. Ancak bu araştırmanın ana konusu şiddetin onaylanmasında değerlerin etkisinin araştırılmasıdır. Çoklu regresyon analizi, en önemli yordayıcıların evrensellik, uyarım, gelenek ve güç olduğunu göstermektedir. Şiddetin panzehri ise eşitlik, bilgelik, barış, çevreyi korumak ve hoşgörü gibi evrensel değerlerdir. Eğitim politikalarında evrensel değerlere önem verilmesi, şiddetin onaylanmasını azaltabilir.

Anahtar Kelimeler: Değerler, şiddetin onaylanması, şiddete maruz kalma, cinsiyet, üniversite öğrencileri.

Acknowledgement: This work was supported by Scientific Research Projects Coordination Unit of Istanbul University. (Project number: 25375).

@

Prof. Istanbul University. vbozkurt@istanbul.edu.tr

Assist. Prof. Harran University. hakangulerce@harran.edu.tr

(C) İlmi Etüdler Derneği

DOI: 10.12658/M0323

insan \& toplum, 2019.

insanvetoplum.org
Başvuru: 29.04.2018

世曲 Revizyon: 01.06.2019

Kabul: 02.08.2019

Online Basım: 22.08.2019 


\section{Introduction}

The main question of this paper is to determine the role values have in predicting violence approval. Violence is known to be one of the most important problems in human history, with high social, economic, and psychological costs. The lives of millions of people are lost each year because of violence, and the economic costs run into billions of pounds (Brown, 2008). Many people suffer mental health problems because of violence. With the evolution of rule of law and democracy, violence has declined to some extent. However, it remains a current global problem throughout all countries (Karstedt, 2006), and the greatest losses from violence are experienced in poor countries. According to the World Health Organization (WHO), more than $90 \%$ of global violence-related deaths occur in low- and middle-income countries.

Violence is a form of power. In a sense, it is power in action. It has many different types, ranging from killing a human being to non-fatal physical injury. Killing is the most extreme form of violence and is thus considered as absolute violence. Nonlethal violence covers a wide range of actions, examples being from a slap all the way to torture (Trotha, 2007). One of the most accepted definitions of violence is the one defined by the WHO, which states that violence is "the intentional use of physical force or power, threatened or actual, against oneself, another person, or against a group or community, that either results in or has a high likelihood of resulting in injury, death, psychological harm, maldevelopment, or deprivation" (Krug et. al., 2002:5).

With the widespread use of the Internet, violence has become more visible, with new technologies also being used by terrorist organizations to commit violent actions on a global scale. Absence of democracy, equality, rule of law, and human rights are among the factors that increase violence. However, violence has deeper roots that are closely related to culture. Values, one of the most important components of a society's culture, are very important in conveying and legitimizing violence.

Many theories exist about the factors that engender violence. Some biological theories explain it through neurological or genetic factors (i.e., the hormone testosterone) or using Freud's Oedipus complex. Some of these theories explain violence through homo-social behaviors, which describe competition among men (Kimmel, 2004; Edwards, 2006; Annagür, 2010; Moore, 2001; Lafrance, 2004; Pope \& Englar-Carlson, 2001). Connell (1996) claimed that boys learn violence from the examples of their fathers. 
Sociology has shown the emphasis on violence to have made changes in the social structure. Anomie, inequality, poverty socialization, and subcultural issues in particular are the most emphasized issues (Heimer, 1997; Trotha, 2007). According to functionalist theory, violence in society is not evenly distributed; it is particularly more prevalent among low socio-economic groups. Abundant data also are found indicating the fact that violence is related to low socio-economic status (Magura, 1975; Wolfgang \& Ferracuti, 1967; Mulvihill, Tumin \& Curtin 1970). The more that people in low socioeconomic groups experience frustrations and deprivations, the more likely they are to have violent reactions (Gelles \& Murray, 1979).

One of the most studied topics in violence is subculture theory. Subculture is defined as "a group with certain characteristics that enable it to be distinguished from other groups and the wider society from which it has emerged" (Muggleton, 2007:4877) Subculture theory explains the use of violence through the group values that justify violent behavior. Violent behavior is the result of values that endorse violence. However, a subculture of violence is not entirely separate from national culture.

According to subculture theory, adhering to the values of groups that approve violence increases aggressive behavior through socialization and social control within the group. For example, a significant relationship exists for the emphasis cultures have on the value of honor or masculinity with violence endorsement (Bozkurt, Tartanoğlu, \& Dawes, 2015). Just as in other subculture groups, a violent subculture is also thought to share certain values. According to this theory, examining the subcultures (and their values) in which people are involved is necessary for understanding why people are violent, because the behaviors of those who exhibit violent behavior are in harmony with the attitudes and values of their own groups.

Values are a basic element of subculture theory. Despite the criticism of this theory (Ball-Rokeach, 1973; Lee \& Ousey, 2011), numerous studies have shown that individuals who endorse certain values show more aggressive behavior. Those who adopt the values of violence tend to be more inclined towards offensive behavior and to respond aggressively to provocations (Bernburg \& Thorlindsson, 2005; Baron, Kennedy, \& Forde, 2001; McGloin, et.al., 2011, Heimer, 1997; Kubrin \& Weitzer, 2003; Markowitz \& Felson, 1998).

Most research has found a positive relationship between violent values and aggressive behavior. The more people have values that support violence, the more 
aggressive they are. According to findings from a large number of researchers, neighborhood street culture significantly predicts violent delinquency (Wolfgang \& Ferracuti, 1967; Ellison 1991; Agnew, 1994; Smith, 1979; Heimer, 1997; Markowitz \& Felson, 1998; Bernburg \& Thorlindsson, 2005; Stewart \& Simons, 2010).

To summarize, a number of reasons exist that lead to violence with different theories that explain it. However, violence is also a part of culture. It is learned via the socialization process through the modeling and emulation of behavior and is closely related to values.

Values are the abstract criteria that tell us what is right and wrong, and they are highly influential in shaping behaviors. Rokeach (1973:5) defined values as "an enduring belief that a specific mode of conduct or end-state of existence is personally or socially preferable to an opposite or converse mode of conduct or end-state of existence," and Schwartz (1992:4) as "desirable, trans-situational goals, varying in importance, that serve as guiding principles in people's lives.”

According to Rokeach, values are limited in number, but attitudes number in the thousands. Values are broader and deeper than attitudes. Values have the criteria of 'should' and 'ought to.' Rokeach stated that values are shaping factors rather than elements of attitudes. Furthermore, values are the most important components of culture, which Hofstede (2003) defined as "collective programming of the mind" or "software of the mind."

A values system also shapes the foundation of a society's reward and punishment system. A society without values means the most powerful tool for social control has also been lost. Values state what is required of people and what is forbidden to them, thereby determining what will be rewarded and what will be punished. Values are sustained in embedded experiences. As Durkheim stated, the identity of a community cannot be considered separate from its set of values (Bozkurt, 2017; Cheney, 2013).

According to Rokeach's (1979) and Schwartz's (1992, 2006, 2007; Schwartz \& Bilsky, 1987) theories, values are the beliefs, ideals, and core concepts used as a means of evaluating the social value of people and goods. They define preferred targets that promote action. Values show the idealistic way of thought and social action in every society, describing a socially tolerable behavior scheme. People understand through their values how best to show their actions. 
Values are used as standards or criteria that template how to evaluate people and policies. They help people know where they are in the eyes of the community. Values are not forms of tangible action, but suggestions for a specific way of life. They have an abstract role in forming social identity and rationalizing and are ranked according to priorities. Moreover, this hierarchical characteristic differentiates values from attitudes and norms (Rokeach, 1979; Schwartz, 2006).

The relative importance of values lie in their capacity to lead to action. Values guide people in choosing and implementing social roles. They construct awareness and inspire. In this way, people become aware of what is requested and anticipated with respect to numerous roles. They are the application of social pressure and social control. Values encourage individuals to obey rules and do "right" things; they also prevent unapproved behavior. Values also function as solidarity tools. People become close with others who share similar values. Common values are one of the most important factors in creating social solidarity. Moreover, values can redirect prominent social change in communities and countries, as well as able to read to social change (Schwartz, 2006, Fichter, 1996; Williams, 1979).

Survey research on values goes back to the 1950s. One of the most well-known studies in this field was conducted by Almond and Verbra (1963), in which they studied the relationship between the political system and culture in the USA, Germany, Mexico, Italy, and England. In the 1960s, Smith and Inkeles (1966) at Harvard University developed the Overall Modernity Scale (OM Scale) in order to comparatively measure modernization trends in societies. This research also foreran the World Values Survey (WVS), which was established by Inglehart in the 1970s (Inkeles \& Smith, 1974; Bozkurt, 2018).

This study uses the Human Values Scale developed by Schwartz (2007) for measuring values. Schwartz's scale has been the most widely used measure of values over the last 20 years. The scale used in this study consisted of 57 items comprising 10 value types. These values are power, achievement, hedonism, stimulation, self-direction, universalism, benevolence, tradition, conformity, and security (see Table 1). These 10 value types are classified under the four super-dimensions of self-enhancement versus self-transcendence, and openness to change versus conservatism (Schwartz, 2007). 


\begin{tabular}{ll}
\hline Table 1. Motivational Types of Values (Schwartz, 1994) \\
\hline Power & $\begin{array}{l}\text { Social status and prestige, control or dominance over people } \\
\text { and resources }\end{array}$ \\
\hline Achievement & $\begin{array}{l}\text { Personal success through demonstrating } \\
\text { competence according to social standards }\end{array}$ \\
\hline Hedonism & Pleasure and sensuous gratification for oneself \\
\hline Stimulation & Excitement, novelty, and challenge in life \\
\hline Self Direction & $\begin{array}{l}\text { Independent thought and action - choosing, creating, } \\
\text { exploring }\end{array}$ \\
\hline Universalism & $\begin{array}{l}\text { Understanding, appreciation, tolerance, and protection for } \\
\text { the welfare of all people and for nature. }\end{array}$ \\
\hline Benevolence & $\begin{array}{l}\text { Preservation and enhancement of the welfare of people with } \\
\text { whom one is in frequent personal contact }\end{array}$ \\
\hline Tradition & $\begin{array}{l}\text { Respect for, commitment to, and acceptance of the customs } \\
\text { and ideas that traditional culture or religion provide for the self }\end{array}$ \\
\hline Conformity & $\begin{array}{l}\text { Restraint of actions, inclinations, and impulses likely to upset } \\
\text { or harm others and violate social expectations or norms }\end{array}$ \\
\hline
\end{tabular}

Power, achievement, hedonism, stimulation, and self-direction, which are common in Western societies, are individualistic values, whereas benevolence, tradition, and conformity, which are common in Eastern societies, are collectivistic values. However, universalism and security serve both. Individual values are focused on self-centered goals. In contrast, collectivist societies, tending toward benevolence, tradition, and conformity, highlight group goals while power values stress social superiority and domination of others. Stimulation values place emphasis on a daring and exciting life (Schwartz, 1992; 1994; Ryckman \& Houston, 2003). All these features can lead to justifying violence in cases of frustration and deprivation.

Tradition can either justify or prevent violence according to a country's cultural characteristics. In societies where historically violence is decisively rejected, the values of tradition can reduce violence. In Turkish culture, tradition justifies violence (Battaloğlu, Çifçi, \& Değer, 2013; Göka, 2008). 
Universalism and self-direction are related to intellectual openness, whereas power and security are more associated with uncertainty control. The main source of motivation for universal values is to work for the well-being of all people (Schwartz \& Boehnke, 2004). In a sense, humanistic universal values are those that can limit the violent behavior that compels others to their own ends. Thus, values can be said to be able to increase or decrease violence.

The subculture theory briefly mentioned above is important in terms of understanding the effect of a culture (i.e., its values) on violence. However, in subculture theory, the relationship between values and violence has been examined in connection with highly-disadvantaged groups prone to violence. Nevertheless, values not only show the effect of human behavior on subculture groups but also influence the behavior of all individuals to a certain extent.

Sundberg (2014) stated security values to have a positive correlation with endorsing violence. In addition, the values of conformity and tradition have been correlated with violent child-rearing. Knafo, Daniel, and Khoury-Kassabri (2008) found violent behavior to have a negative correlation with conformity and universalism among high school students, whereas power values have a positive relation. In that research, values that predict violent behavior explain $12 \%$ of the variance. The academic literature has an extremely limited number of studies examining the direct relationship of values and violence.

This paper also examines the impact of gender and exposure to violence on the approval of violence, because gender is closely associated with violence. The more people are exposed to violence in daily life, the more they endorse violence (Contreras \& Cano, 2016; Özgür, Yörükoğlu, \& Baysan-Arabac1, 2011; Ayan, 2007; Güleç et. al., 2012; Avcı \& Yıldırım, 2014). Males are known to legitimize violence more than females (Rodriguez Martinez \& Khalil, 2017). Most of the perpetrators of violence are men, and the targets are women (Mills, 2001; Kimmel \& Mahler, 2003). In many cultures, violence is seen as a way of gaining the male identity (Kimmel, 2004; Rubenser, 2007). Violent warrior values have always been associated with male stereotypes (Campbell, 2006).

Although the primary purpose of this study is not to investigate the relationship between gender and violence, gender is an influential factor both on values and on the approval of violence (Bozkurt, Tartanoğlu, \& Dawes, 2015). Therefore, gender and exposure to violence have been included in the second stage of the study using hierarchical regression. 
The aim of this research is to provide a contribution to the academic literature in an area that has not been sufficiently studied. Thus, it will help the reader understand the motivational sources of violence in the context of Turkish culture. There are three research questions in this paper:

1. Do values make a difference in violence endorsement among university students?

2. Which values better predict violence endorsement?

3. Does violence exposure and gender make a difference in violence endorsement?

\section{Method}

The stratified random-sampling method has been used in the research. A total of 1,024 questionnaires were taken into consideration. The number of females (512) and males (512) was kept equal because gender is known to affect both values and violence. The sample was applied to undergraduate students of the social sciences in a university in Turkey. The students' ages range from 17 to 28 years old. An attempt has been made to achieve a balanced distribution of the sample over the four years of classes.

The purpose of the questionnaire was explained briefly to the students, who had voluntarily participated in the survey. The questionnaire was completed by undergraduate students in approximately 10-15 minutes with the support of students and the lecturers in the classrooms. Any questionnaires lacking full answers to all of the questions were excluded, and to ensure the male-female balance, some of the female surveys were not evaluated.

As more female students attend than males, the number of female students who answered the questionnaire was higher. To equalize the numbers for each gender, a limited number of female students' questionnaires were randomly deleted from the data. This number did not affect the results.

The questionnaire applies the long Schwartz' Values Survey (SVS) consisting of 57 questions. This is one of the most used scales for currently measuring values. Responses require that values are considered as a guiding principle for life, scored as -1 (opposed to my values), 0 (not important), 3 (important), 6 (very important), and 7 (supremely important). 
The reliability coefficients of the 10 dimensions obtained for values from the scale were as follows: universalism, 77; tradition, 63; conformity, 60; benevolence, 73; self-direction, 61; stimulation, 60; hedonism, 67; achievement, 69; power, 70; and security, 67 . These coefficients are in parallel with previous applications of the scale.

In addition to the SVS, the Violence Culture Scale (VCS) has been used to measure violence approval. This scale was developed by Bozkurt, Tartanoğlu, and Dawes (2015) and consists of 10 questions and two sub-dimensions (violence endorsement and exposure to violence; see Table 2). A 5-point Likert scale was used where 1 = strongly disagree, 2 = disagree, 3 = undecided, 4 = agree, and $5=$ strongly agree.

Table 2. Violence Culture Scale Rotated Component Matrix ${ }^{a}$

Component

1-. $\quad 2-$

VIOLENCE ENDORSEMENT-- Cronbach's Alpha $=.77$

If necessary, violence can be used to resolve disputes

Exerting violence is sometimes normal

.832

Fighting and/or self-defense sports should be taught to children from an early age

I am against all kinds/types of violence $\mathbf{R}$

.551

Knives and guns have always attracted me

.543

I enjoyed interacting with violent games and movies when I was a child

VIOLENCE EXPOSURE- Cronbach's Alpha $=.73$

When I was child, I never knew when my parents would reward me or punish me

When I was a child, violence was seen as punishment from heaven .799

I was exposed to physical violence when I was a child .746

I have done physical violence to others in the past .542

Explained variance: $54.2 \%$

$36.4 \% \quad 17.7 \%$

${ }^{a}$ Extraction Method: Principal Component Analysis. Rotation Method: Varimax with Kaiser Normalization. Total Explained Variance: 54 2\%; KMO = 789; Overall Cronbach's Alpha $=0.80$. 
Cronbach's alpha value of the scale's factor of violence endorsement is 0.77; violence exposures Cronbach's alpha value is 0.73 . After re-encoding the reversescored question, Cronbach's alpha value for the overall scale is 0.80 .

\section{Results}

Table 3 shows the mean scores and standard deviations for the variables used in the analyses. The scores for the values range from 4.27 to 6.05. In the Schwartz' Values Survey, a score of 4 or higher corresponds to the options that are important or very important. The values with the lowest averages (means) are stimulation, power, tradition, and hedonism. The top priority values have been determined as security, benevolence, self-direction, and universalism. The standard deviations for the low priority values have been found to be high, while the $S D$ s for the high priority values are lower than expected.

Table 3. Descriptive Statistics: Means and Standard Deviations

\begin{tabular}{llll}
\hline & $M$ & $N$ & $S D$ \\
\hline Conformity & 5.3582 & 1,024 & 1.15966 \\
\hline Tradition & 4.5683 & 1,024 & 1.34464 \\
\hline Benevolence & 5.7640 & 1,024 & .98069 \\
\hline Universalism & 5.5375 & 1,024 & .98917 \\
\hline Self-Direction & 5.7205 & 1,024 & .91855 \\
\hline Stimulation & 4.2754 & 1,024 & 1.52530 \\
\hline Hedonism & 4.8481 & 1,024 & 1.49496 \\
\hline Achievement & 5.1846 & 1,024 & 1.27101 \\
\hline Power & 4.5687 & 1,024 & 1.45814 \\
\hline Security & 6.0533 & 1,024 & .94853 \\
\hline Violence Endorsement & 2.3580 & 1,024 & .87768 \\
\hline Violence Exposure & 1.9783 & 1,024 & .88145 \\
\hline
\end{tabular}

A 5-point Likert-type response scale has been used for the questions in the Violence Culture Scale (VCS), where $2=$ disagree and $3=$ undecided. The mean for the factor of violence endorsement is 2.35 , and the mean for the factor of violence exposure is 1.97. 
Pearson correlation analysis has been used to determine the relationship between values and violence. The analysis reveals a statistically significant and positive correlation for the values of tradition $(r=.070, p<0.05)$, stimulation $(r$ $=.199, p<0.05)$ and power $(r=.119, p<0.05)$ with violence endorsement. In other words, people who value stimulation, power, and tradition are more likely to endorse violence. Violence is quite common in traditional Turkish culture (Battaloğlu, Çifçi, \& Değer, 2013, Göka, 2008).

Violence endorsement displays a significant and negative correlation with the values of conformity $(r=-.149, p<0.05)$, benevolence $(r=-.105, p<0.05)$, universalism $(r=-.242, p<0.05)$, and security $(r=-.108, p<0.05)$. These results were in line with the findings from the only research on this topic (Knafo, Daniel, \& Khoury-Kassabri, 2008). This study by Knafo et al. was conducted on Palestinian and Jewish high school students in Israel. The results showed a statistically significant and negative correlation for violent behavior with benevolence, universalism, and conformity among the high school students. A negative correlation was determined for approval of violence with the values of power and stimulation. These results differ from the current study's findings with respect to the values of tradition, achievement, and hedonism.

No significant relationship was determined for the values of hedonism, selfdirection, and achievement with violence endorsement. When examining the correlations by separating the data according to gender, a statistically significant and positive correlation is determined between hedonism and violence endorsement in males $(r=.144, p<0.05)$ but not for females $(r=-.061, p>0.05)$. Thus, violence can be said to be pleasurable for some males.

A fairly high and positive correlation has been determined between violence endorsement and violence exposure $(r=.394, p<0.05)$. As people are exposed to violence, they become more and more consenting toward violence. In other words, those who grow up in a violent social environment are more likely to endorse violence.

A positive correlation $(r=.071, p<0.05)$ exists between the value of stimulation and violence exposure. The value of stimulation consists of items such as adventure, risk, daring, variety, excitement, and challenges in life. On the other hand, violence exposure has a significant correlation with the values of conformity $(r=-.187, p<$ $0.05)$, benevolence $(r=-.102, p<0.05)$, achievement $(r=-.082, p<0.05)$, and security $(r=-.193, p<0.05)$. People who grow up in an environment of violence are more removed from the values of humanism, benevolence, self-direction, and conformity. 
Table 4. Correlations for Human Values with Violence Endorsement and Violence Exposure According to Gender

\begin{tabular}{|c|c|c|c|c|c|c|c|c|c|c|c|c|c|c|}
\hline & & 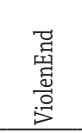 & 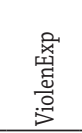 & ڤ & 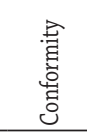 & 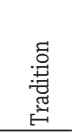 & 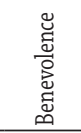 & 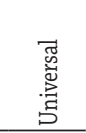 & 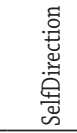 & $\begin{array}{l}\text { 含 } \\
\text { 营 } \\
\text { 葛 }\end{array}$ & 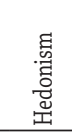 & 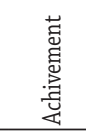 & 岕 & $\begin{array}{l}\text { 壳 } \\
\text { 心 } \\
\text { 心 }\end{array}$ \\
\hline \multirow{2}{*}{$\begin{array}{l}\text { Violence } \\
\text { Endorsement }\end{array}$} & $\begin{array}{l}\text { Pearson } \\
\text { Correlation }\end{array}$ & 1 & $.394^{* *}$ & $.479^{* *}$ & $-.149^{* *}$ & $.070^{*}$ & $-.105^{* *}$ & $-.242^{* *}$ & -.053 & $.199^{* *}$ & .043 & .036 & $.119^{* *}$ & $-.108^{* *}$ \\
\hline & $\begin{array}{l}\text { Sig. } \\
\text { (2-tailed) }\end{array}$ & & .000 & .000 & .000 & .026 & .001 & .000 & .090 & .000 & .167 & .249 & .000 & .001 \\
\hline \multirow{2}{*}{$\begin{array}{l}\text { Violence } \\
\text { Exposure }\end{array}$} & $\begin{array}{l}\text { Pearson } \\
\text { Correlation } \\
\end{array}$ & $.394^{* *}$ & 1 & $.272^{* *}$ & $-.187^{* *}$ & -.018 & $-.102^{* *}$ & $-.160^{* *}$ & $-.067^{*}$ & $.071^{*}$ & -.045 & $-.082^{* *}$ & -.030 & $-.193^{* *}$ \\
\hline & $\begin{array}{l}\text { Sig. } \\
\text { (2-tailed) }\end{array}$ & .000 & & .000 & .000 & .561 & .001 & .000 & .031 & .024 & .150 & .009 & .333 & .000 \\
\hline \multirow{2}{*}{$\begin{array}{l}\text { Sex 1.Women } \\
\text { 2.Men }\end{array}$} & $\begin{array}{l}\text { Pearson } \\
\text { Correlation } \\
\end{array}$ & $.479^{* *}$ & $.272^{3 *}$ & 1 & $-.174^{* *}$ &,- 008 & $-.126^{* *}$ & $-.163^{* *}$ & -.003 & $.114^{* *}$ &,- 016 & -.039 & -.020 & $-.137^{* *}$ \\
\hline & $\begin{array}{l}\text { Sig. } \\
\text { (2-tailed) }\end{array}$ & .000 & .000 & & .000 & .792 & .000 & .000 & .928 & .000 & .614 & .215 & .523 & .000 \\
\hline \multirow[b]{2}{*}{ Conformity } & $\begin{array}{l}\text { Pearson } \\
\text { Correlation } \\
\end{array}$ & $-.149^{* \prime}$ & $-.187^{* *}$ & $-.174^{* *}$ & 1 & $.533^{* *}$ & $.613^{* *}$ & $.517^{\prime \prime}$ & $.285^{* *}$ & $.121^{* *}$ & $.139^{* *}$ & $.407^{* *}$ & $.267^{* *}$ & $.606^{* *}$ \\
\hline & $\begin{array}{l}\text { Sig. } \\
\text { (2-tailed) }\end{array}$ & .000 & .000 & .000 & & .000 & .000 & .000 & .000 & .000 & .000 & .000 & .000 & .000 \\
\hline \multirow[b]{2}{*}{ Tradition } & $\begin{array}{l}\text { Pearson } \\
\text { Correlation }\end{array}$ & $.070^{*}$ & -.018 & -.008 & $.533^{* *}$ & 1 & ,514" & 339** & ,146" & "157" &, $078^{*}$ & 291" &, $246^{* *}$ &, $429^{* *}$ \\
\hline & $\begin{array}{l}\text { Sig. } \\
\text { (2-tailed) }\end{array}$ & .026 & .561 & .792 & .000 & & .000 & ,000 &, 000 & ,000 & ,012 & .000 & .000 & .000 \\
\hline \multirow{2}{*}{ Benevolence } & $\begin{array}{l}\text { Pearson } \\
\text { Correlation }\end{array}$ & $-.105^{* *}$ & $-.102^{* *}$ & $-.126^{* *}$ & $.613^{* *}$ & $.514^{* *}$ & 1 & $.612^{* *}$ & $.423^{* *}$ & $.174^{\prime \prime \prime}$ & $.179^{* *}$ & $.363^{* *}$ & $.174^{* *}$ & $.493^{* *}$ \\
\hline & $\begin{array}{l}\text { Sig. } \\
\text { (2-tailed) }\end{array}$ & .001 & .001 & .000 & .000 & .000 & & .000 & .000 & .000 & .000 & .000 & .000 & .000 \\
\hline \multirow{2}{*}{ Universal } & $\begin{array}{l}\text { Pearson } \\
\text { Correlation }\end{array}$ & $-.242^{* *}$ & $-.160^{* *}$ & $-.163^{* *}$ & $.517^{* *}$ & $.339^{* *}$ & $.612^{* *}$ & 1 & $.492^{\prime \prime}$ & $.258^{* *}$ & $.264^{* *}$ & $.348^{* *}$ & $.197^{* *}$ & $.458^{* *}$ \\
\hline & $\begin{array}{l}\text { Sig. } \\
\text { (2-tailed) }\end{array}$ & .000 & .000 & .000 & .000 & .000 & .000 & & .000 & .000 & .000 & .000 & .000 & .000 \\
\hline \multirow{2}{*}{ SelfDirection } & $\begin{array}{l}\text { Pearson } \\
\text { Correlation } \\
\end{array}$ & -.053 & $-.067^{*}$ & -.003 & $.285^{* *}$ & $.146^{* *}$ & $.423^{* *}$ & $.492^{* *}$ & 1 & $.439^{\prime *}$ & $.414^{* *}$ & $.444^{* *}$ & $.301^{* *}$ & $.292^{* *}$ \\
\hline & $\begin{array}{l}\text { Sig. } \\
\text { (2-tailed) }\end{array}$ & .090 & .031 & .928 & .000 & .000 & .000 & .000 & & .000 & .000 & .000 & .000 & .000 \\
\hline \multirow{2}{*}{ Stimulation } & $\begin{array}{l}\text { Pearson } \\
\text { Correlation } \\
\end{array}$ & $.199^{* *}$ & $.071^{\circ}$ & $.114^{* *}$ & $.121^{* *}$ & $.157^{*}$ & $.174^{* *}$ & $.258^{* \prime}$ & $.439^{* *}$ & 1 & $.438^{* *}$ & $.428^{* *}$ & $.409^{* *}$ & $.176^{* *}$ \\
\hline & $\begin{array}{l}\text { Sig. } \\
\text { (2-tailed) }\end{array}$ & .000 & .024 & .000 & .000 & .000 & .000 & .000 & .000 & & .000 & .000 & .000 & .000 \\
\hline \multirow{2}{*}{ Hedonism } & $\begin{array}{l}\text { Pearson } \\
\text { Correlation }\end{array}$ & .043 & -.045 & -.016 & $.139^{* *}$ & $.078^{*}$ & $.179^{* *}$ & $.264^{* \prime}$ & $.414^{* *}$ & $.438^{\prime \prime}$ & 1 & $.378^{* *}$ & $.423^{* *}$ & $.174^{* *}$ \\
\hline & $\begin{array}{l}\text { Sig. } \\
\text { (2-tailed) }\end{array}$ & .167 & .150 & .614 & .000 & .012 & .000 & .000 & .000 & .000 & & .000 & .000 & .000 \\
\hline \multirow{2}{*}{ Achivement } & $\begin{array}{l}\text { Pearson } \\
\text { Correlation }\end{array}$ & .036 & $-.082^{* *}$ & -.039 & $.407^{* *}$ & $.291^{* *}$ & $.363^{* *}$ & $.348^{* *}$ & $.444^{* *}$ & $.428^{* *}$ & $.378^{* *}$ & 1 & $.614^{* *}$ & $.390^{* *}$ \\
\hline & $\begin{array}{l}\text { Sig. } \\
\text { (2-tailed) }\end{array}$ & .249 & .009 & .215 & .000 & .000 & .000 & .000 & .000 & .000 & .000 & & .000 & .000 \\
\hline \multirow{2}{*}{ Power } & $\begin{array}{l}\text { Pearson } \\
\text { Correlation }\end{array}$ & $.119^{* *}$ & -.030 & -.020 & $.267^{* *}$ & $.246^{* *}$ & $.174^{* *}$ & $.197^{\prime \prime}$ & $.301^{* *}$ & $.409^{* *}$ & $.423^{* *}$ & $.614^{* *}$ & 1 & $.323^{* *}$ \\
\hline & $\begin{array}{l}\text { Sig. } \\
\text { (2-tailed) }\end{array}$ & .000 & .333 & .523 & .000 & .000 & .000 & .000 & .000 & .000 & .000 & .000 & & .000 \\
\hline \multirow{2}{*}{ Security } & $\begin{array}{l}\text { Pearson } \\
\text { Correlation } \\
\end{array}$ & $-.108^{* *}$ & $-.193^{* *}$ & $-.137^{* *}$ & $.606^{*}$ & $.429^{* *}$ & $.493^{* *}$ & $.458^{* *}$ & $.292^{* *}$ & $.176^{* *}$ & $.174^{* *}$ & $.390^{* *}$ & $.323^{* *}$ & 1 \\
\hline & $\begin{array}{l}\text { Sig. } \\
\text { (2-tailed) }\end{array}$ & .001 & .000 & .000 & .000 & .000 & .000 & .000 & .000 & .000 & .000 & .000 & .000 & \\
\hline \multicolumn{15}{|c|}{ Correlation is significant at the $\boldsymbol{p}<0.01$ level (2-tailed). } \\
\hline
\end{tabular}


A strong positive correlation has been determined for males with violence in both dimensions, similar to the results of other studies (Bozkurt, Tartanoğlu, \& Dawes, 2015; Çakmak \& Çelik, 2016; Rodriguez Martinez, \& Khalil, 2017; Mills, 2001; Kimmel \& Mahler, 2003; Rubenser, 2007; Campbell, 2006). The obtained results are as expected, as the fact that prisons throughout the world are full of men is no coincidence.

Multiple regression analysis has been applied to predict the combined effects of values. In order to only see the variance explained in the regression analysis, the 10 variables are taken together. The adjusted $R^{2}$ explains $16 \%$ of the variance in violence endorsement. Although the variance rate explained by the 10 values is not very large, it is quite significant. In the subsequent stage in accordance with Schwartz's recommendation, the three variables with no significant correlation to violence endorsement are excluded from the first regression model.

The second phase of hierarchical multiple regression analysis also includes gender and violence exposure. The adjusted variance (adjusted $R^{2}$ ) increased to .372 . Gender was the most important indicator for predicting violence endorsement $(\beta=$ $.356, t=13.489, p<0.05)$. The second predictive variable is exposure to violence $(\beta$ $=.249, t=9.421, p<0.05)$. In the hierarchical multiple regression model, the values of universalism $(\beta=-.240, t=-7.173, p<0.05)$, stimulation $(\beta=.143, t=5.056$,

$p<0.05)$, and power $(\beta=.099, t=3.462, p<0.05)$ are predictive variables. The strongest predictive value in the regression analysis again is universalism $(\beta=-.38$, $t=-8.286, p<0.05)$. In the second model of the hierarchical multiple regression analysis, the other variables had no significant effect.

\section{Discussion}

A culture of violence refers to choosing violence as a problem-solving method. In other words, a culture of violence increases aggression (Luckenbill \& Doyle, 1989). Data show that victims of violence have greater approval of violence, and this has been confirmed by findings from studies on the thesis of violence subculture. However, the current study was not restricted to a subculture group with violent behavior, as in the theory, because the sample was taken from a group of university students. 
Table 5. Hierarchical Regression-Analysis Summary for Variables Predicting Violence Endorsement

\begin{tabular}{|c|c|c|c|c|c|c|c|}
\hline Variables & $\beta$ & $t$ & $S D$ & Sig. & $R$ & $R^{2}$ & Adj. $R^{2}$ \\
\hline Step 1 & & & & & 0.41 & 0.17 & 0.16 \\
\hline Constant & 3.15 & & 0.19 & .00 & & & \\
\hline Conformity & -.099 & -3.09 & .032 & .00 & & & \\
\hline Tradition & .125 & 5.34 & .023 & .00 & & & \\
\hline Benevolence & .039 & 1.03 & .038 & .30 & & & \\
\hline Universalism & -.282 & -8.29 & .034 & .00 & & & \\
\hline Stimulation & .135 & 7.30 & .019 & .00 & & & \\
\hline Power & .050 & 2.52 & .020 & .01 & & & \\
\hline Security & -.050 & -1.424 & .035 & .15 & & & \\
\hline Step 2 & & & & & 0.61 & .38 & 0.37 \\
\hline Constant & 1.12 & 5.68 & .197 & .00 & & & \\
\hline Conformity & -.036 & -1.28 & .028 & .20 & & & \\
\hline Tradition & .076 & 3.73 & .020 & .00 & & & \\
\hline Benevolence & .034 & 1.05 & .033 & .29 & & & \\
\hline Universalism & -.213 & -7.17 & .030 & .00 & & & \\
\hline Stimulation & .082 & 5.06 & .016 & .00 & & & \\
\hline Power & .060 & 3.46 & .017 & .00 & & & \\
\hline Security & .001 & .048 & .031 & .96 & & & \\
\hline $\begin{array}{l}\text { Violence } \\
\text { Exposure }\end{array}$ & .248 & 9.42 & .026 & .00 & & & \\
\hline Gender & .625 & 13.49 & .046 & .00 & & & \\
\hline
\end{tabular}

The strongest predictor in the regression model is the value of universalism ( $\beta$ $=-.317, t=-8.286, p<0.05)$. In the first model, the values of stimulation $(\beta=.235$, $t=7.300, p<0.05)$, tradition $(\beta=.191, t=5.340, p<0.05)$, and conformity $(\beta=$ $-.131, t=-3.089, p<0.05)$ are also significant predictors of violence approval. Seven values from the first model explain $16 \%$ of the variance. 
This undergraduate sample revealed the relationship between values and violence endorsement. A positive relationship has been determined between traditional values and the approval of violence in the study. Traditional values include items such as respect for tradition, accepting my place in life, avoiding extremes of feelings and action, and being modest and conservative. Not all these items positively correlate to violence approval. Some items (albeit not significantly) have a negative correlation, such as those related to modesty and humility. However, most items related to traditional values have been determined to have a positive correlation with the approval of violence because violence is one of the most important features of the socialization process in the traditions of Turkey. A Turkish proverb says, "The beating comes from heaven," and there are many idioms about the virtue of physical violence. The process of Turkish modernization has seen a partially increased awareness of the damage of violence on a child's socialization, although violence remains a means of socializing. One Turkish author (Göka, 2008) has claimed that Turks have a warrior mindset that stems from their history.

Violence is an action with risks, so the fact that those who adopt stimulation values in search of excitement, adventure, and risk in life are more likely to endorse violence than others is no surprise. Violence and stimulation cause similar emotions in the individual. In other words, violence is a form of stimulation. For example, sexual excitement and violence manifest themselves in the same way, with most measurable bodily reactions behaving the same in both cases (Girard, 2003). Both violence and stimulation are a challenge that involves risk taking and excitement with basic biological impulses.

Nietzsche (1968) argued that mankind is driven by the will to power as the main motivation for all actions. Power increases man's chances of survival, and one of its most important means is violence. Violence, as an instrument of power, intimidates opponents and provides access to resources. Moreover, some writers have claimed that personal power inhibits the ability to empathize (Keltner, Van Kleef, Chen, \& Kraus, 2008). Low empathy makes it hard to understand other people's suffering (Eagleman, 2015), so the existence of a positive relationship between power values and approval of violence is no surprise.

Data have shown the antidote to violence to be universal values. Universal values consist of values such as equality, social justice, a peaceful world, pro-environment, wisdom, beauty, and tolerance to different ideas and beliefs. These are humanistic values that protect the well-being of all people. An increase in universal values in the world would contribute to world peace and the reduction of violence. 
One of the most important problems, however, is the fact that identities are based on the other. Therefore, those who want to build a community identity see universal values as an obstacle because, as stated by Sennet (1996), if you have an enemy, you feel a sense of brotherhood.

The most commonly used way to try to strengthen loyalty to an identity (group integration) is to encourage tension between different identities, especially in countries that have not developed individuality and are late to modernization. The encouragement of universal values could play an important role in reducing violence endorsement.

\section{Limitations and Implications}

The control of violence is vital towards creating a more livable world. The most important limitation of this research is that it only included university students and is therefore not representative of the general population. Future research would be more meaningful if the population consisted of a more representative sample.

However, despite the limitations, these data provide a significant contribution to the understanding of the relationship among values, gender, and violence. Based on the results of this study, policymakers could revise the school syllabus. Values education is a topic that is currently on the agenda in Turkey, as in many other countries.

Of course, values are not the only cause of violence, but the data show a relationship to exist between values and violence endorsement. Policymakers could help to reduce violence in the future by considering the consequences of such research.

More awareness could be created about values such as stimulation, power, and tradition. In order to reduce violence endorsement, humanistic universal values can be emphasized in values education programs.

The data obtained in this study show once more that violence causes violence because the victims of violence adopt violence as a way of solving a problem or as a survival strategy. Therefore, in the process of socialization, parents and policymakers should develop mechanisms to control traditional approaches that see violence as part of a child's education. 


\section{References}

Almond, G., \& Verba, S. (1963). The Civic Culture: Political Attitudes and Democracy in Five Nations. Sage Publications Inc.

Annagur, B. (2010). Sağlık çalışanlarına yönelik şiddet: Risk faktörleri, etkileri, değerlendirilmesi ve önlenmesi. Psikiyatride Güncel Yaklaşımlar, 2(2).

Avci, Ö. H., \& Yildirim, İ. (2014). Ergenlerde şiddet eğilimi, yalnızlık ve sosyal destek. Hacettepe Üniversitesi Eğitim Fakültesi Dergisi, 29(29-31).

Ayan, S. (2007). Aile içinde şiddete uğrayan çocukların saldırganlık eğilimleri. Anadolu Psikiyatri Dergisi, 8(3), $206-214$.

Ball-Rokeach, S. J. (1973). Values and violence: A test of the subculture of violence thesis. American Sociological Review, 736-749.

Baron, S. W., Kennedy, L. W., \& Forde, D. R. (2001). Male street youths' conflict: The role of background, subcultural, and situational factors. Justice Quarterly, 18(4), 759-789.

Battaloğlu-İnanç, B., Çifçi, S., \& Değer, V. (2013). Mardin ili ilköğretim okulu öğrencilerinin fiziksel şiddete maruziyetleri ve yaklaşımları. Türk Pediatri Arşivi, 48(3).

Bernburg, J. G., \& Thorlindsson, T. (2005). Violent values, conduct norms, and youth aggression: A multilevel study in Iceland. The Sociological Quarterly, 46(3), 457-478.

Bozkurt, V. (2017). Değişen Dünyada Sosyoloji. Ekin Kitabevi, Bursa.

Bozkurt, V. (2018). Values in Turkey, in The Modernizing Process in Turkey, Edit.H. Karakus, Nomos, Germany.

Bozkurt, V., Tartanoğlu, S., \& Dawes, G. (2015). Masculinity and violence: Sex roles and violence endorsement among university students. Procedia-Social and Behavioral Sciences, 205, 254-260.

Brown, D. W. (2008). Economic value of disability-adjusted life years lost to violence: estimates for WHO Member States. Revista Panamericana de Salud Publica, 24(3), 203-209.

Çakmak, M. N., \& Çelik, V. O. (2016). Futbolda şiddet ve erkeklik: Nefer taraftar grubu örneği, Sosyoloji Konferanslari/ Istanbul Journal of Sociological Studies, 54(2), 299-331.

Campbell, A. (2006). Sex differences in direct aggression: What are the psychological mediators?. Aggression and Violent Behavior, 11(3), 237-264.

Cheney, G. (2013), Values, in Sociology of Work: An Encyclopedia / Edited by V. Smith, SAGE Publications.

Connell, R. W. (1996). Teaching the boys: New research on masculinity, and gender strategies for. Teachers College Record, 98(2), 206-235.

Contreras, L., \& Cano, M. C. (2016). Social competence and child-to-parent violence: Analyzing the role of the emotional intelligence, social attitudes, and personal values. Deviant Behavior, 37(2), 115-125.

Eagleman, D. (2015). The brain: The story of you. Vintage.

Edwards, T. (2006). Cultures and masculinities. New York: Routledge.

Fichter, J., (1996). Sosyoloji nedir?, Attila Kitabevi.

Gelles, R. J., \& Straus, M. A. (1979). Determinants of violence in the family: Toward a theoretical integration. pp. 549-581 in Contemporary Theories about the Family, edited by Wesley R. Burr et. al. New York: Free Press.

Girard, R. (2003). Şiddet ve Kutsal. Tr. N. Alpay, Kanat.

Göka, E. (2008). Türklerin Psikolojisi. Timaş Yayınları, İstanbul.

Güleç, H., Topaloğlu, M., Ünsal, D., \& Altıntaş, M. (2012). Bir kısır döngü olarak şiddet. Psikiyatride Güncel Yaklaşımlar, 4(1).

Heimer, K. (1997). Socioeconomic status, subcultural definitions, and violent delinquency. Social Forces, 75(3), 799-833.

Hofstede, G. (2003). Culture's Consequences: Comparing values, behaviors, institutions and organizations across nations. Sage publications.

Inkeles, A., \& Smith D. H. (1974). Becoming Modern: Individual Change in Six Developing Countries. Cambridge: Harvard Univ Press. 


\section{insan \& toplum}

Karstedt, S. (2006). Democracy, values, and violence: Paradoxes, tensions, and comparative advantages of liberal inclusion. The Annals of the American Academy of Political and Social Science, 605(1), 50-81.

Keltner, D., Van Kleef, G. A., Chen, S., \& Kraus, M. W. (2008). A reciprocal influence model of social power: Emerging principles and lines of inquiry. Advances in Experimental Social Psychology, 40, 151-192.

Kimmel, M. (2004).Violence in Men and Masculinities: A social, cultural, and historical encyclopedia, Edited by Michael Kimmel and Amy Aronson, Abc-clio Publications.

Kimmel, M. S., \& Mahler, M. (2003). Adolescent masculinity, homophobia, and violence: Random school shootings, 1982-2001. American Behavioral Scientist, 46(10), 1439-1458.

Knafo, A., Daniel, E., \& Khoury-Kassabri, M. (2008). Values as protective factors against violent behavior in Jewish and Arab high schools in Israel. Child Development, 79(3), 652-667.

Krug, E. G., Mercy, J. A., Dahlberg, L. L., \& Zwi, A. B. (2002). The world report on violence and health. The Lancet, 360(9339), 1083-1088.

Kubrin, C. E., \& Weitzer, R. (2003). Retaliatory homicide: Concentrated disadvantage and neighborhood culture. Social Problems, 50(2), 157-180.

Lafrance, M. (2004). Psychoanalysis. Men and masculinities: A social, cultural, and historical encyclopedia. Edited by Michael Kimmel and Amy Aronson, Abc-clio Publications. ABC-CLIO.

Lee, M. R., \& Ousey, G. C. (2011). Reconsidering the culture and violence connection: Strategies of action in the rural south. Journal of Interpersonal Violence, 26(5), 899-929.

Luckenbill, D. F., \& Doyle, D. P. (1989). Structural position and violence: Developing a cultural explanation. Criminology, 27(3), 419-436.

Magura, S. (1975). Is there a subculture of violence?. American Sociological Review, 40(6), 831-836.

Markowitz, F. E., \& Felson, R. B. (1998). Social-demographic attitudes and violence. Criminology, 36(1), 117-138.

McGloin, J., Schreck, C. J., Stewart, E. A., \& Ousey, G. C. (2011). Predicting the violent offender: The discriminant validity of the subculture of violence. Criminology, 49(3), 767-794.

Mills, M. (2001). Boys and violence in schools: Everybody's business. Education Views, 16.

Moore, T. (2001). Sex roles, in The Gale encyclopedia of psychology Edited by Bonnie R. Strickland, 2nd ed., pp. 578581.

Muggleton, D. (2007). Subculture in Blackwell encyclopedia of sociology, Edited by G. Ritzer, Malden: Blackwell.

Mulvihill, D. J. Tumin, M. M., \& Curtis, L. A. (1970). Crimes of violence: a staff report submitted to the National Commission on the Causes \& Prevention of Violence (Vol. 3). For sale by the Supt. of Docs., US Govt. Print. Off.

Nietzsche, F. (1968). The will to power. W. Kaufmann \& R. J. Hollingdale (Trans.). New York, NY: Vintage.

Özgür, G., Yörükoğlu, G., \& Baysan-Arabacı, L. (2011). Lise öğrencilerinin şiddet algıları, şiddet eğilim düzeyleri ve etkileyen faktörler. Psikiyatri Hemşireliği Dergisi, 2(2), 53-60.

Pope, M., \& Englar-Carlson, M. (2001). Fathers and sons: The relationship between violence and masculinity. The Family Journal, 9(4), 367-374.

Rodriguez Martinez, P., \& Khalil, H. (2017). Changing values: Attitudes about intimate partner violence in immigrants and natives in five Western countries. Deviant Behavior, 38(3), 241-253.

Rokeach, M. (1973). The Nature of Human Values. New York: The Free Press

Rokeach, M. (1979). From individual to institutional values: With special reference to the values of science. Understanding human values, 47, 70.

Rubenser, L. (2007). Actors influencing reporting behavior by male domestic violence victims. Encyclopedia of Domestic Violence, 308-314.

Ryckman, R. M., \& Houston, D. M. (2003). Value priorities in American and British female and male university students. The Journal of Social Psychology, 143(1), 127-138.

Schwartz, S. H. (1992). Universals in the content and structure of values: Theoretical advances and empirical tests in 20 countries. Advances in Experimental Social Psychology, 25, 1-65. 
Schwartz, S. H. (1994). Are there universal aspects in the structure and contents of human values?. Journal of Social Issues, 50(4), 19-45.

Schwartz, S. H. (2006). A theory of cultural value orientations: Explication and applications. Comparative Sociology, 5(2), 137-182.

Schwartz, S. H. (2007). Universalism values and the inclusiveness of our moral universe. Journal of Cross-Cultural Psychology, 38(6), 711-728.

Schwartz, S. H., \& Bilsky, W. (1987). Toward a theory of the universal content and structure of values: Extensions and cross-cultural replications. Journal of Personality and Social Psychology, 58(5), 878.

Schwartz, S. H., \& Boehnke, K. (2004). Evaluating the structure of human values with confirmatory factor analysis. Journal of Research in Personality, 38(3), 230-255.

Sennett, R. (1996). Kamusal insanın çöküşü, Çev. Durak, S. ve Yılmaz, A., Ayrıntı Yayınları, Istanbul.

Smith, M. D. (1979). Hockey violence: A test of the violent subculture hypothesis. Social Problems, 27(2), $235-247$.

Smith, D. H., \& Inkeles, A. (1966). The OM Scale: A Comparative Socio-Psychological Measure of Individual Modernity. Sociometry, 29(4), 353-377.

Stewart, E. A., \& Simons, R. L. (2010). Race, code of the street, and violent delinquency: A multilevel investigation of neighborhood street culture and individual norms of violence. Criminology, 48(2), 569-605.

Sundberg, R. (2014). Violent values: Exploring the relationship between human values and violent attitudes. Peace and Conflict: Journal of Peace Psychology, 20(1), 68.

Trotha, T. V. (2007). Violence. In Ritzer (Ed.) The Balckwell Encyclopedia of Sociology (Vol. 6, p. 5201).

Williams Jr., R. M. (1979). Change and stability in values and value systems: A sociological perspective. Understanding Human Values, 15-46.

Wolfgang, M. E., Ferracuti, F., \& Mannheim, H. (1967). The subculture of violence: Towards an integrated theory in criminology (Vol. 16). London: Tavistock Publications. 
